\title{
СТИЛІСТИЧНИЙ ПОТЕНЦІАЛ ПОВТОРУ В РОМАНАХ ШАРЛОТТИ БІНГХЕМ
}

\section{Гайденко Ю. О.}

\section{ВСТУП}

Одним із важливих складників художнього твору як структурносмислового цілого $є$ синтаксис, котрий через поєднання стилістично нейтральних i маркованих синтагм не лише відображає авторську модальність, а й зумовлює певну когнітивну реакцію читача. Чільне місце серед стилістично маркованих синтагм, утворених у результаті цілеспрямованих естетичних пошуків автора, посідає синтактикостилістична фігура повтору, що допомагає розставити необхідні комунікативні акценти в лексико-синтаксичному полотні художнього твору, виконує низку стилістичних функцій, слугує досягненню стилістичного ефекту й допомагає створити певний психологічний настрій читача.

Повтор - це фігура мовлення, що полягає в повторенні звуків, слів, морфем, синонімів або синтаксичних конструкцій в умовах достатньої тісноти ряду, тобто розташованих достатньо близько один від одного, для того щоб їх можна було помітити. У лінгвістичній літературі існує два підходи щодо інтерпретації повтору. 3 одного боку, у ньому вбачають надлишковий елемент, що не надає додаткову предметно-логічну інформацію в межах синтаксичної конструкції, до якої він входить. 3 іншого боку, повтор уважають засобом вираження додаткових відтінків експресивного, емотивного (емоційного), оцінного та стилістичного характеру, що накладаються на основний логіко-предметний зміст у межах певного синтаксичного цілого й виражають суб'єктивне ставлення мовця до предмета мовлення, підвищують емоційний вплив певного мовленнєвого відрізка через виділення прагматично значущої інформації, причому іноді за рахунок використання повтору «предметнологічну інформацію буває важко відділити від додаткової прагматичної» ${ }^{1}$

Комплексним дослідженням синтактико-стилістичної фігури повтору присвячено роботи таких мовознавців, як І.В. Арнольд (2016), М.П. Брандес (1990), В.А. Кухаренко (2016), О.М. Мороховський (1991), Ю.М. Скребнєв (2003) та ін. Означена проблема не втрачає актуальності

1 Арнольд И.В. Стилистика. Современный английский язык. 13-е изд., испр. и доп. Москва : Флинта : Наука, 2016. 384 с. 
в мовознавчих студіях сьогодення, тому різні ії аспекти висвітлено в низці наукових праць. Зокрема, типологічні різновиди повтору описано в розвідках Ю.Ю. Волянської (2010), Т.В. Жук (2005), Н. Кемертелідзе (2003) та ін. Поза тим у роботах Н.I. Власюк (2016), 3.В. Бандурко (2019) повтор розглядається як інструмент прагматичного впливу на адресата, Л.В. Мужеловської (2012), В.А Чабаненко (2002) - стилістичний засіб творення експресії, В.М. Фінів (2019), А.А. Чередніченко (2014) знаряддя когезії тексту. Актуальними у контексті означеної тематики $\epsilon$ праці І. Надірадзе (2016), котра досліджує функціювання повтору в англомовних новелах XX століття, І.В. Соколової (2002), яка розглядає його роль у забезпеченні ефективності комунікації на матеріалі текстіванонсів сучасних британських видань, Г.І. Сташко (2015), яка аналізує використання повтору в американських фольклорних піснях. Проте, попри наявність лінгвістичних досліджень, присвячених синтактикостилістичній фігурі повтору, його репрезентація в романах англійськомовної авторки-сучасниці Шарлотти Бінгхем досі не вивчались ані вітчизняними, ні зарубіжними мовознавцями, що зумовлює актуальність цього дослідження.

Класифікаційними ознаками повтору в сучасних мовознавчих студіях слугують його структурні, функційні, семантичні, стилістичні характеристики. Типологізація повторів у пропонованій праці виходить із принципу рівневої організації системи мови. Особливу увагу ми надаємо повторам на лексичному та синтаксичному рівнях, подальший розподіл яких виходить із мовознавчих позицій категорій форми і змісту повторюваних елементів речення, висловлювання або надфразної єдності.

Мета дослідження - розглянути лексичний і синтаксичний повтори, здійснити їх типологізацію, визначити їх кількісне співвідношення та схарактеризувати їх стилістичні функції в романах Шарлотти Бінгхем.

Матеріалом дослідження слугували 4697 синтактико-стилістичних фігур повтору, дібрані методом суцільної вибірки з 10 романів Шарлотти Бінгхем: „In Sunshine or in Shadow” (1991), „Stardust” (1993), „Change of Heart” (1994), „Grand Affair” (1997), „The Kissing Garden” (1999), „Distant Music” (2002), „Magic Hour” (2005), „Out of the Blue” (2006), „The White Marriage” (2007), „The Daisy Club” (2009).

\section{1. Лексичний повтор у романах Шарлотти Бінгхем}

Лексичний повтор - це повторення слова або словосполучення в складі одного речення, абзацу або цілого повідомлення ${ }^{2}$. У сучасних лінгвістичних дослідженнях лексичний повтор розглядають як такий,

2 Арнольд И.В. Стилистика. Современный английский язык. 13-е изд., испр. и доп. Москва : Флинта : Наука, 2016. 384 с. 
що виконує семантичну чи/і стилістичну функції. Зокрема, Ю.А. Бєльчиков стверджує, що повтори мають два призначення: поперше, забезпечують зв'язність мовлення, виступаючи важливим текстотворчим компонентом; по-друге, підвищують виразність, експресивність мовлення, зумовлюють його динамічність ${ }^{3}$.

Розгляд лексичного повтору як стилістичної категорії пов'язано 3 тим, що повторення лексичної одиниці у писемному мовленні зумовлюється наміром автора, у кожному наступному реченні повторювати саме те слово попереднього відрізка тексту, що має актуалізувати особливе смислове навантаження. Так, згідно 3 Г.М. Акімовою, форма усного мовлення дозволяє використовувати надлишковість у вигляді лексичного повтору для того, щоб краще донести інформацію до слухача, а оскільки „основою письмових експресивних конструкцій слугує розмовний субстрат", лексичний повтор екстраполюють у писемне художнє мовлення для відображення усного мовлення персонажів, їхнього емоційного стану. Звідси лексичний повтор має інтенційну природу й виступає ефективним інструментом емоційно-смислової домінанти тексту.

Як зазначає Н.І. Власюк, повтор не просто спрямований на конкретного адресата, а й зумовлює його реакцію: провокує його на бажану для адресанта поведінку чи дію у відповідь.

Повтор лексичної одиниці 3 метою іiі смислового чи емоційного підсилення спирається на принцип упорядкованості, який виражається через уживання повторюваного елемента в певній позиції, тобто у визначеному місці в реченні чи його частині, надфразній єдності, тексті. Продуктивними в дослідженні $є$ класифікації повторів I.В. Арнольд ${ }^{6}$, М.О. Мороховського та ін. ${ }^{7}$. Основними критеріями класифікації лексичного повтору слугують принцип упорядкованості повторюваних лексичних одиниць у межах речення або висловлювання й, відповідно, повна чи часткова точність їх відтворювання за формою та змістом. Ураховуючи ці критерії, лексичний повтор поділяється нами на низку розглянутих нижче фігур.

3 Бельчиков Ю.А. Нужно воспринимать жизнь во всем ее блеске, красоте и богатстве красок : к 100-летию со дня рождения К.Г. Паустовского. Рус. яз. в шк. 1992. № 2. C. 31-36.

4 Акимова Г.Н. Новое в синтаксисе современного русского языка. М. : Высш. шк., 1990. 168 с.

5 Власюк Н.И. Синонимический повтор в прагматическом аспекте. Bonpocbl лингводидактики: сборник научных работ. Гродно: ООО «ЮрСаПринт», 2016. C. $46-48$.

6 Арнольд И.В. Стилистика. Современный английский язык. 13-е изд., испр. и доп. Москва : Флинта : Наука, 2016. 384 с.

7 Стилистика английского языка / А.Н. Мороховский, О.П. Воробьёва, Н.И. Лихошерст, 3.В. Тимошенко. Киев : Вища школа, 1991. 241 с. 
Простий контактний повтор $(3,4 \%)$ - це багаторазове використання одного слова чи словосполучення, що займають у реченні контактну позицію ${ }^{8}$. Шарлоттою Бінгхем цей тип повтору вживається насамперед у діалогах персонажів, максимально реалістично відтворюючи розмовне мовлення. Причому повторювані лексичні одиниці можуть належати до різних частин мови й розташовуватися пре-, пост- чи інтерпозитивно стосовно інших елементів висловлювання: 'Girls, girls, look, here is your cousin Alexandra. ${ }^{9}$; When Dmitry Boska said there was something to see, there was something to see ${ }^{10}$. У романах письменниці цей різновид повтору використовується передусім для вираження емоційного стану персонажів-мовців, а його стилістична значущість зворотно пропорційна кількості повторень лексичної одиниці. Число повторюваних елементів слугує вказівкою на ступінь емоційної збудженості персонажа.

Романи Шарлотти Бінгхем також містять простий контактний повтор, формально виражений двочленними сполученнями, зокрема сполучниковими: night after night тощо чи прийменниковими: home from home $\boldsymbol{h}^{\text {II }}$. 3 одного боку, змістові характеристики такого повтору варіюються, а 3 іншого - він виконує функцію просторово-часової характеризації з указівкою міри, ступеня: She had allowed him to go, deeper and deeper into the woods, further and further from her side, and had returned to the dance ${ }^{12}$.

Розширений повтор $(1,4 \%)$ - це повторення мовленнєвої одиниці 3 додатковими елементами, що уточнюють або розширюють іiі значення ${ }^{13}$. Його стилістичне призначення в романах Шарлотти Бінгхем полягає в підсиленні емоційності всього висловлювання, а також змісту повторюваної одиниці й деталізації основної думки висловлювання через наділення повторюваного різними інформаційнохарактерологічними відтінками: It was the smell. It was the awful overpowering sickening smell ${ }^{14}$.

Подібно до простого контактного повтору, стилістична значущість розширеного може зумисно підсилюватися авторкою для збагачення мовлення персонажів семантикою підвищеної емоційності через

8 Кухаренко В.А. Практикум по стилистике английского языка. Москва : Флинта : Наука, 2009. 184 с.

${ }^{9}$ Bingham C. Magic Hour. London : Bantam Books, 2005. 416 p.

${ }^{10}$ Bingham C. Stardust. London : Bantam Books, 1993. 576 p.

${ }^{11}$ Bingham C. The Daisy Club. London : Bantam Books, 2009. 480 p.

${ }^{12}$ Bingham C. Stardust. London : Bantam Books, 1993. 576 p.

13 Стилистика английского языка / А.Н. Мороховский, О.П. Воробьёва, Н.И. Лихошерст, 3.В. Тимошенко. Киев : Вища школа, 1991. 241 с.

${ }^{14}$ Bingham C. Distant Music. London : Bantam Books, 2002. 576 p. 
збільшення числа вживань певної лексичної одиниці: 'It's like a nervous tic for me - quoting, quoting, always quoting ${ }^{15}$.

Кільцевий повтор або обрамлення (2,2\%) - це повторення мовленнєвої одиниці на початку й у кінці висловлювання ${ }^{16}$. У романах Шарлотти Бінгхем він виконує не лише експресивно-стилістичну функцію, виділяючи важливу в контексті висловлювання інформацію, а й стильову, позначаючи просторічне мовлення персонажів, через повтор підмета, вираженого особовим займенником, і присудка або його частини на початку й у кінці речення. Причому характерною особливістю романів авторки є підсилення значущості кінцевого члена кільцевого повтору через використання в його складі пре- або інтерпозитивного прислівника-інтенсифікатора really, truly тощо: 'It's absurd really, you know. We've known each other since we were children, so it is truly, really-absurd! ${ }^{17}$.

Повтор-підхоплення (3,3\%) - це повторення кінцевого елемента висловлювання на початку іншого чи повтор на стику двох конструкцій задля конкретизації висловленого ${ }^{18}$. Шарлоттою Бінгхем цей тип повтору здебільшого використовується для увиразнення діалогічного мовлення персонажів, виконуючи не лише експресивно-стилістичну, а й стильову функцію. Повтор-підхоплення слугує засобом відображення розмовного мовлення персонажів, що зумовлено фізіологічними особливостями індивіда та різними позамовними чинниками комунікативної ситуації, що доводиться конвергенцією цього типу повторів 3 апозіопезисом, причому повторюватися можуть як повнозначні, так і службові частини мови: 'I suppose ... I suppose I said it because, well, because I was in such a bate about being found out!' ${ }^{19}$.

На відміну від висловлювань, у яких повтор-підхоплення використовується як засіб інтенсифікації обриву мовлення, конструкції зі звичайним повтором-підхопленням експлікують значно вищий ступінь упевненості персонажа-мовця, а також використовуються в (не)власне авторському мовленні для підвищення виразності й образності романів: Besides, what he felt or rather had felt for Diane Smith-Werner wasn't love. Love didn't enter into it ${ }^{20}$.

${ }^{15}$ Bingham C. The Kissing Garden. London : Bantam Books, 1999. 624 p.

${ }^{16}$ Скребнев Ю.М. Основы стилистики английского языка. 2-е. изд., испр.; на англ. яз. Москва : Астрель, 2003. 221 с.

${ }_{18}^{17}$ Bingham C. The Kissing Garden. London : Bantam Books, 1999. 624 p.

18 Гринишин У.М. Синтаксичний повтор як домінанта експресивного маркування постмодерністського тексту. Украӥнознавчі студіï. 2013. С. 75-82.

${ }^{19}$ Bingham C. The White Marriage. London : Bantam Books, 2007. 480 p.

${ }^{20}$ Bingham C. Change of Heart. London : Bantam Books, 1994. 469 p. 
У монологічному та діалогічному персонажному мовленні романів Шарлотти Бінгхем повтор-підхоплення може виконувати функцію зворотного зв'язку: 'Hart? Hart will take anything from flak to your best evening jacket ${ }^{21}$; 'I want you to promise me that you will always love me whatever.' - 'Whatever? I don't understand. Whatever what? ${ }^{22}$.

Ланиюжсковий повтор (0,1\%) - це поєднання декількох повторівпідхоплень ${ }^{23}$. Ланцюжковий повтор зустрічається в романах Шарлотти Бінгхем значно рідше від повторів інших типів, привертаючи увагу читача до речення, у структуру якого його включено. Він виконує функцію смислового зчеплення контактно розташованих речень або частин складнопідрядних речень, експлікує послідовність, причиннонаслідкові зв'язки, сповільнений характер перебігу подій: If you show you're nervous it will make him nervous, and if you make him nervous he will feel nervous about what you have to say, and if he's nervous about what you have to say he won't feel like investing in you ${ }^{24}$.

Етимологічний повтор $(1,1 \%)$ - це повторення (здебільшого контактне) у межах одного висловлювання близьких за значенням спільнокореневих слів, що належать до різних частин мови. У романах Шарлотти Бінгхем він володіє значною стилістичною значущістю, привертаючи увагу читача формально-змістовими характеристиками спільнокореневих слів: Alexandra sat down quite suddenly remembering not to cross her ankles, which Tasha Millington had always told the girls was 'beyond the beyonds, 25 .

Отже, у романах Шарлотти Бінгхем наявні всі різновиди лексичного повтору. Найбільш поширеними є простий контактний $(3,4 \%)$, повторпідхоплення $(3,3 \%)$ та кільцевий $(2,2 \%)$. Розширений $(1,4 \%)$ та етимологічний $(1,1 \%)$ повтори в романах авторки зустрічаються рідше, а вживання ланцюжкового повтору $(0,1 \%)$ Шарлотті Бінгхем майже не властиве.

\section{2. Синтаксичний повтор у романах Шарлотти Бінгхем}

Синтаксичний повтор - фігура мовлення, яка розширює синтаксичну структуру речення або висловлювання, відтворюючи формальну та семантичну структуру поняття, яке повторюється та передбачає «цілеспрямоване відхилення від нейтральної синтаксичної норми, для

${ }^{21}$ Bingham C. The White Marriage. London : Bantam Books, 2007. 480 p.

${ }^{22}$ Bingham C. The Kissing Garden. London : Bantam Books, 1999. 624 p.

23 Гальперин И.Р. Очерки по стилистике английского языка. Москва : ЛИБРОКОМ, 2016. 376 с.

${ }^{24}$ Bingham C. Distant Music. London : Bantam Books, 2002. 576 p.

${ }^{25}$ Bingham C. Magic Hour. London : Bantam Books, 2005. 416 p. 
якої достатньо одноразового використання певного слова» ${ }^{26}$. Основним критерієм класифікації синтаксичного повтору в дослідженні слугує принцип повторення синтаксичної позиції лексичної одиниці чи структурно-синтаксичної моделі в кожному наступному (контактно розташованому) реченні або його частині 3 (частково) відмінним лексичним наповненням. Ураховуючи ці критерії, синтаксичний повтор поділяється нами на низку розглянутих нижче фігур.

Анафоричний повтор (5,3\%) - це повторення початкового елемента в низці речень, що слідують одне за одним ${ }^{27}$. Його стилістична функція полягає в підвищенні змістової ваги речення, акцентуації уваги читача на елементах, що повторюються. У романах Шарлотти Бінгхем цей різновид повтору реалізується за допомогою лексем і синтаксем: People drank wine, they ate, they turned first to the right, and then to the left, they conversed, they aired their opinions, they agreed with each other ${ }^{28}$; She got on with_her dancing and her singing lessons. She got on with her dancing classes at Tippy Toes. She got on with her ballet shoes. She got on with the washing-up ${ }^{29}$.

Характерною ознакою романів авторки є анафоричне повторення синтаксичної моделі з додатковими елементами, що уточнюють або розширюють їі значення: 'Study your history, my son. Study your social history and you will see mistress and maid, lord and lover, 30 .

Eniфоричний повтор (0,9\%) - це повтор кінцевого елемента в низці двох або більше речень, що слідують одне за одним. У мовознавчій літературі його функцію пов'язують із забезпеченням ритмічної організації мовлення ${ }^{31}$. У романах Шарлотти Бінгхем епіфоричний повтор, подібно до анафоричного, реалізується лексемами та синтаксемами: They are not a couple, they don't look like a couple ${ }^{32}$; All it required was a sudden smile or just a special way of walking. Elizabeth had a special way of walking ${ }^{33}$.

${ }^{26}$ Арнольд И. В. Стилистика. Современный английский язык. 13-е изд., испр. и доп. М. : Флинта : Наука, 2016. 384 с.

27 Nadiradze I. Lexical repetition as a characteristic feature of the English and Georgian novellas. Scientific enquiry in the contemporary world: theoretical basics and innovative approach: Scientific articles. $7^{\text {th }}$ edition. USA : B\&M Publishing. 2016. P. 101-106.

${ }^{28}$ Bingham C. The Daisy Club. London : Bantam Books, 2009. 480 p.

${ }^{29}$ Bingham C. Distant Music. London : Bantam Books, 2002. 576 p.

${ }^{30}$ Bingham C. The White Marriage. London : Bantam Books, 2007. 480 p.

${ }^{31}$ Ахманова О.С. Словарь лингвистических терминов. Москва : УРСС, 2004. $571 \mathrm{c.}$

${ }^{32}$ Bingham C. Magic Hour. London : Bantam Books, 2005. 416 p.

${ }^{33}$ Bingham C. Stardust. London : Bantam Books, 1993. 576 p. 
Приклади анафоричного та епіфоричного повторів Шарлотти Бінгхем засвідчують, що вони виконують архітектонічну функцію, забезпечуючи граматичну й логічну зв'язність частин одного або суміжних висловлювань, слугують засобом стильової орієнтації читача, зокрема відображення розмовного стилю мовлення, у діалогічному мовленні виражають емоційне ставлення персонажів, слугують засобами ритмічної організації мовлення, а в композиційно-мовленнєвих формах підвищують образність художнього викладу думки.

Симплока $(0,3 \%)$ - це комбінація анафори й епіфори в структурі двох або більше суміжних висловлювань (строф, абзаців тощо) $)^{34}$, причому для іiі утворення достатньо повного відтворення першої та часткового останньої чи навпаки: 'Yet all you remember is this incessant noise. Fantastic noise. Noise such as you have never heard before, noise like a thousand thunderstorms happening all at once' [35, с. 59]. У романах Шарлотти Бінгхем стилістична функція симплоки полягає в акцентуації уваги читача на повторюваних елементах, ритмізації певного відрізка мовлення.

Синонімічний повтор (12,4\%) - це повтор, що полягає у використанні синонімічних лексичних засобів для позначення певної реалії, процесу, дії, їхніх властивостей ${ }^{35}$. Його стилістична функція пов'язана 3 виділенням різних відтінків лексичного значення синонімічних слів. Цей повтор часто переплітається із синтаксичним, адже синонімічні лексичні засоби часто належать до однорідних членів речення. У романах Шарлотти Бінгхем синонімічний повтор слугує засобом уникнення тавтології, зосереджує увагу на повторюваному члені висловлювання чи надфразної єдності й може виконувати функцію додаткової характеризації позначуваного через внесення нових емоційних, експресивних, оцінних, образних відтінків: And like the Cowardly Lion and the Tin Man in The Wizard of $\mathrm{Oz}$, the out of work actors and the resting thespians would now be hiding in terror at the mere mention of Elsie Lancaster until the Wicked Witch of the West retired once more to her kitchen ${ }^{36}$.

Синтаксичним повтором $€$ перелічення й такі його ускладнені різновиди, як акумуляція та ампліфікація. Перелічення (35\%) - це фігура стилістичного синтаксису, що створюється в результаті повторення однорідних синтаксичних одиниць різного обсягу (як окремих членів

34 Скребнев Ю.М. Основы стилистики английского языка. 2-е. изд., испр. Москва : Астрель, 2003. 221 с.

${ }^{35}$ Брандес М.П. Стилистика немецкого языка. 2-е изд. Москва : Высшая школа, 1990. $320 \mathrm{c}$.

${ }^{36}$ Bingham C. Distant Music. London : Bantam Books, 2002. 576 p. 
речення, так і словосполучень) у рамках завершеного висловлювання ${ }^{37}$. Воно грунтується на семантичному процесі розширення, за якого до певної синтаксичної одиниці в структурі речення додаються інші одиниці такого ж порядку та поєднуються 3 першою певним видом зв'язку. Звідси в мовознавчій літературі перелічення, з одного боку, пов'язують із градацією, яка насамперед стосується стилістичної семасіології, аз іншого - 3 асиндетоном і полісиндентоном, котрі належать до сфери стилістичного синтаксису. У романах Шарлотти Бінгхем перелічення представлено широкою варіативністю моделей, які слугують засобом конкретизації інформації, деталізованого опису предметів та явищ, підкреслення кількості й різноманіття реалій навколишньої об'єктивної дійсності: At first she saw nothing as she played, no images or landscapes, no people or places ${ }^{38}$; 'It's just that you need so many changes of clothes,' Amelia complained. 'For shooting, lunching, walking, rowing, playing tennis, taking tea, drinks, dinner ${ }^{39}$.

Перелічення в межах складного речення утворюється через включення до складу останнього подібних підрядних речень або простих, об'єднаних сурядним зв'язком, які, взаємодіючи, утворюють паратаксичний ланцюг. Згідно 3 I.В. Арнольд, така взаємодія синтаксичних структур у межах складного речення утворює специфічний різновид повтору - синтаксичну конвергенцію, тобто групу з декількох елементів, що, співпадаючи за функцією, об'єднані однаковим синтаксичним відношенням стосовно слова чи речення, якому вони підпорядковані ${ }^{40}$; звідси синтаксично однорідні частини складного речення становлять окремий випадок повторення на синтаксичному рівні. Залежно від наявності формально вираженого семантичного підсумку в кінці синтаксичної конвергенції виділяється два типи фігур: акумуляція та ампліфікація.

Акумуляція (6,5\%) - це стилістична фігура накопичення, яка полягає в нагромадженні в межах одного речення або надфразної єдності конструкцій чи їх частин, формально виражених підрядними реченнями або простими, об'єднаними сурядним зв'язком, що слідують одне за одним, виконують одну синтаксичну функцію, підпорядковуються одному базовому слову чи реченню, характеризуючи певну реалію навколишньої дійсності, процес, дію тощо: Laura too started to laugh, but as she did so, her hand flew up to her mouth to stop a

37 Стилистика английского языка / А.Н. Мороховский, О.П. Воробьёва, Н.И. Лихошерст, 3.В. Тимошенко. Киев : Вища школа, 1991. 241 с.

${ }^{38}$ Bingham C. Change of Heart. London : Bantam Books, 1994. 469 p.

${ }^{39}$ Bingham C. The Kissing Garden. London : Bantam Books, 1999. 624 p.

40 Арнольд И.В. Стилистика. Современный английский язык. 13-е изд., испр. и доп. Москва : Флинта : Наука, 2016. 384 с. 
sudden sob as she remembered how divine Gerald Hardwick had looked on his magnificent grey hunter, how elegant his figure in his beautifully cut hunting coat, how handsome the set of his head on his slim shoulders ${ }^{41}$.

Ампліфікація $(1,2 \%)$ - це стилістична фігура накопичення, за якої, на відміну від акумуляції, кінцевий ефект нагромадження синтаксично паралельних структур підсилюється замикальною фразою, що слугує формально-семантичним узагальненням-підсумком їх сукупного змісту (іншими словами, ампліфікується). Ампліфікація в романах Шарлотти Бінгхем представлена різними моделями та характеризується значною стилістичною значущістю. По-перше, вона реалізується в межах речення, займаючи пре-, інтер- чи постпозицію: From the first she could sense that the owner of the apartment must be very rich indeed, not just because the furnishings were so understated, the materials at the windows and on the beds, the linen sheets, the coffee machine, the navy blue and white china - everything in the flat was so perfectly, acceptably rich, and out of the reach of most people except the very rich - but because it smelt rich $^{42}$. По-друге, iï стилістична значущість актуалізується в межах надфразної єдності, останнє речення якої слугує загальним висновком попередньо вжитих паралельних синтаксичних конструкцій. При цьому ампліфікація може розгортатися на рівні багатьох або двох речень, де перше - це завжди складнопідрядна чи сурядна синтаксична структура: In the next minutes, as the noise and chatter swelled around her, and the sunlight filtered through the windows on to the variety of stuffs and feathers, sequins and buttons, tiny swathes of silk velvets, flowers and veiling, the realisation gradually came to her that she had been freed from her toys and her old school books, from the pink and white curtains of her room with the bobbled fringe that ran down the sides, from the steady, unvaried life of Rushington, from her parents' silently reproachful eyes, from the nighttime sound of the hunting owl hooting on its way to the Downs; from the Vauxhall breaking down; from Clem Arkwright's Garage; from the butcher who liked to tease her as if she was still a schoolgirl. She had been freed from the whole tangle of her ordinary, happy childhood ${ }^{43}$.

Зазначені вище приклади перелічення (а також ампліфікації й акумуляції) кваліфікують його як синтактико-стилістичну фігуру, якій завідомо властивий моносиндетичний зв'язок, що поєднує одним сполучником два члени речення. Перелічувані елементи пов'язуються в межах певної синтаксичної структури в безсполучниковий (асиндетичний), багатосполучниковий (полісиндетичний) або змішаний спосіб, тому тип зв'язку, що виникає між ними, є важливою

\footnotetext{
${ }^{41}$ Bingham C. Magic Hour. London : Bantam Books, 2005. 416 p.

${ }^{42}$ Bingham C. Distant Music. London : Bantam Books, 2002. 576 p.

${ }^{43}$ Bingham C. The White Marriage. London : Bantam Books, 2007. 480 p.
} 
синтаксичною характеристикою перелічення, збагачуючи висловлювання додатковими експресивно-стилістичними відтінками.

Асиндетичний зв'язок (3,7\%) - це різновид сурядного зв'язку, що з'єднує елементи, які перелічуються в безсполучниковий спосіб. У романах Шарлотти Бінгхем він є значно менш продуктивним типом зв'язку порівняно 3 полісиндетичним. Речення 3 асиндетоном характеризуються лаконічністю викладу інформації, акцентуючи увагу читача на перелічуваних елементах. Його стилістичний ефект у межах синтаксичних будов зворотно пропорційний кількості членів і синтагм, пов'язаних у безсполучниковий спосіб: Amelia had eyes only for George, trusting that he would not falter, thinking that he was as strong as he looked. ${ }^{44}$; Slowly carriage doors started to open, and then decorously, brusquely, hurriedly, ponderously, the different passengers stepped down and out on to the platform ${ }^{45}$.

На противагу полісиндетичному зв'язку, уведення якого в структуру речення, висловлювання або надфразної єдності забезпечує розміреність, протяжність викладу авторської думки, використання письменницею асиндетона надає синтаксичній будові різкості, суворості й може зумисно використовуватися в будь-яких композиційно-мовленнєвих формах чи персонажному діалогічному мовленні для відображення емоційно напружених комунікативних ситуацій, надаючи висловлюванню ефекту квапливості: The butler threw open the door. - 'A young lady came for the interview,' he announced from the door the woman finished writing something. She finally looked up. 'Sit down,' she said. Arietta sat down carefully and with due consideration to the usual niceties: no crossing of ankles, skirt to be arranged decorously, gloved hands held loosely in the lap ${ }^{46}$.

Полісиндентичний зв'язок (2,8\%) - це тип синтаксичного повтору, різновид сурядного зв'язку, що з'єднує більшу кількість елементів, які перелічуються, супроводжуючи кожен сполучником ${ }^{47}$. Найбільш продуктивним засобом сполучникового зв'язку в романах Шарлотти Бінгхем є сполучник and, котрий пов'язує як однорідні члени речення, так і підрядні речення: Then when уоu leave to explore the rest of the gardens you are drawn away from the house by a series of walkways and paths, all of which will lead through gates and archways, stone and iron near the house and then natural entrances and exits cut from hedgerow and trees the further afield you venture ${ }^{48}$.

${ }^{44}$ Bingham C. The Kissing Garden. London : Bantam Books, 1999. 624 p.

${ }^{45}$ Bingham C. Distant Music. London : Bantam Books, 2002. 576 p.

${ }^{46}$ Bingham C. The White Marriage. London : Bantam Books, 2007. 480 p.

${ }^{47}$ Брандес М.П. Стилистика немецкого языка. 2-е изд. Москва : Высшая школа, 1990. $320 \mathrm{c}$.

${ }^{48}$ Bingham C. The Kissing Garden. London : Bantam Books, 1999. 624 p. 
Також спостерігаються висловлювання 3 повторенням інших координативних і субординативних сполучників підрядності, зокрема but, yet, after, although (though), (as) if, because, or, when, where тощо. Стилістична значущість висловлювань із точки зору полісиндетичного зв'язку зворотно пропорційна кількості повторюваних сполучників, які $\epsilon$ засобом рематизації - вираження найбільш значущої з позиції авторки частини інформації. При цьому багаторазове повторення сполучників надає розміреності, урівноваженості, протяжності викладу художнього твору: She was required, daily, to attend secretarial college, study, and help around the house, just as if nothing had happened in her life, just as if she was not engaged to Gray Wyndham, just as if she had not scandalised the neighbourhood by acquiring a fiance at what was generally considered far too young an age 49 .

Значною стилістичною значущістю в романах авторки володіють висловлювання або надфразні єдності з кілька- або багаторазовим повторенням декількох типів синдетичного зв'язку, які насамперед застосовуються в діалогічному персонажному або невласне авторському мовленні, інтенсифікуючи загальну семантику емоційної збудженості, надаючи динамізму перебігу подій: First, after her early morning tea, she must change into her housecoat for breakfast in her boudoir, then she must bath and change into a suit in which to give or take lunch at home or in someone else's house; and then a cocktail dress in which to go to drinks, after which a ball gown, or opera coat and dress might be required ${ }^{50}$.

Одним із різновидів повтору на синтаксичному рівні, стилістичним засобом, на якому в більшості випадків грунтуються перелічення, ампліфікація та акумуляція, уважають паралелізм. Паралелізм $(18,1 \%)-$ це стилістичний прийом, що базується на однаковій побудові двох або більше речень чи їх частин. У ньому вбачають системне явище, одну з найважливіших фігур виразності художнього мовлення ${ }^{51}$. Паралелізм надає висловлюванню ритмічного повторення основної ознаки, стану чи властивості та сприяє вираженню глибинного змісту. Із формальної точки зору паралелізм є синтаксичною еквівалентністю сусідніх конструкцій, повтором не окремих слів, а синтаксичної моделі загалом.

Згідно 3 К.М. Абдуллаєвим, паралелізм $є$ одним із основних семантико-структурних засобів оформлення в складі як окремого

${ }^{49}$ Bingham C. The White Marriage. London : Bantam Books, 2007. 480 p.

${ }^{50}$ Bingham C. The White Marriage. London : Bantam Books, 2007. 480 p.

51 Дреева Д.М., Биджелова Б.А. Синтаксический параллелизм в аспекте художественного перевода (на материале стихотворных произведений Ф.Г. Клопштока и И.В. Гете и их переводов на русский и осетинский языки). Современные проблемы науки и образования. 2015. № 2-3. URL: https://www.scienceeducation.ru/ru/article/view?id=23705 (дата звернення: 10.01.2018). 
речення, так і декількох пов'язаних між собою речень ${ }^{52}$, тому залежно від типу й складності конструкцій, що повторюються, його поділяють на мікропаралелізм - засіб організації малих форм - і макропаралелізм - засіб організації великих форм ${ }^{53}$.

Мікропаралелізм - це паралелізм у межах одного речення, за якого один його член (обставина, додаток, означення), утворює паралельні конструкції, що, зокрема, ілюструють синтагми Шарлотти Бінгхем: Jamie Millington looked round the room into which he had been led, and wondered at its oak furniture, its ladderback chairs and three-leaf oval table ${ }^{54}$.

Макропаралелізм - це паралелізм самостійних або низки підрядних речень: And, greatest of all good fortunes, there was a whole day of work ahead of him, a day when he would be paid, when he would be fed, when his mother would be paid, when his mother would be fed ${ }^{55}$;'Who wouldn't want Dilke to have loved you, as you deserved? Who would not want you to have been able to love Dilke as you wanted? ${ }^{56}$.

Подібне використання мікропаралелізму та макропаралелізму авторкою досить поширене й уживається для підкреслення смислової рівнозначності всіх частин речення, логічного зв'язку між його частинами, виконуючи емотивну функцію.

Синтаксична тавтологія (2,3\%) - це повторення тотожних за смислом і граматично синонімічних елементів у структурі речення ${ }^{57}$. У межах цієї синтактико-стилістичної фігури виділяються такі різновиди, як пролепса й тавтологія в приєднувальних твердженнях.

Пролепса, або пролепсис - це повторення члена речення (зазвичай підмета), вираженого іменником, у формі займенника, причому іменник, відокремлений від іншої частини речення за допомогою займенника, ніби відособлюється ${ }^{58}$. Отже, іменник виконує автосемантичну, а займенник - синсемантичну функцію. Шарлоттою Бінгхем пролепса використовується в персонажному діалогічному мовленні для емфатичного підкреслення предмета мовлення й

52 Новрузова Н.С. Синтаксический параллелизм в древнетюркских текстах Вестник Московского государственного лингвистического университета. Серия «Гуманитарные науки». 2013. № 23 (683). С. 60-69.

53 Дрыгина Ю.А. Некоторые особенности синтаксического параллелизма в современной английской научной прозе. Единство системного и функиионального анализа языковых единии: материалы Междунар. науч. конф. Белгород, 2003. Вып. 7. Ч. 1. С. 149-151.

${ }^{54}$ Bingham C. Magic Hour. London : Bantam Books, 2005. 416 p.

${ }^{55}$ Bingham C. Magic Hour. London : Bantam Books, 2005. 416 p.

${ }^{56}$ Bingham C. The White Marriage. London : Bantam Books, 2007. 480 p.

${ }^{57}$ Брандес М. П. Стилистика немецкого языка. 2-е изд. Москва : Высшая школа, $1990.320 \mathrm{c}$.

58 Скребнев Ю.М. Основы стилистики английского языка. 2-е. изд., испр. Москва : Астрель, 2003. 221 с. 
функційно-стильової орієнтації читача: 'Lady Stourton, she loves horses, 'Fleur insisted ${ }^{59}$.

Тавтологія в приєднувальних твердженнях - це повтор сукупного змісту речення за допомогою приєднувального висловлювання, яке $є$ абстрактною схемою попереднього речення, засобом відтворення всієї синтаксичної структури речення в схематизованому вигляді. Приєднувальне твердження складається 3 двох елементів: підмета, вираженого займенником, і присудка, маніфестованого допоміжним чи модальним дієсловом ${ }^{60}$. Цей різновид синтаксичної тавтології використовується Шарлоттою Бінгхем насамперед у невласне авторському та персонажному діалогічному мовленні, слугуючи засобом відображення функційно-стильових відтінків. Формальнозмістова структура приєднувального твердження може розширюватися через додавання прислівників-інтенсифікаторів семи емоційності really, certainly, of course, so тощо, які можуть займати пре- чи постпозицію, а саме приєднувальне твердження може набувати статусу парцелята: 'I think everyone's gone mad, I do really ${ }^{61}$.

Отже, романи Шарлотти Бінгхем налічують усі означені вище різновиди синтаксичного повтору. Найбільш поширеними 3-поміж них $\epsilon$ перелічення (35\%), паралелізм (18,1\%) і синонімічний повтор (12,5\%). Менш численні - акумуляція (6,5\%), анафора (5,3\%), асиндетон (3,7\%), полісиндетон $(2,8 \%)$ і синтаксична тавтологія (2,5\%). Ампліфікація $(1,3 \%)$, симплока $(0,4 \%)$ та епіфора $(0,2 \%)$ є найменш репрезентативними.

Відсоткове співвідношення різновидів лексичного та синтаксичного повторів у романах Шарлотти Бінгхем зображено на рис. 1.

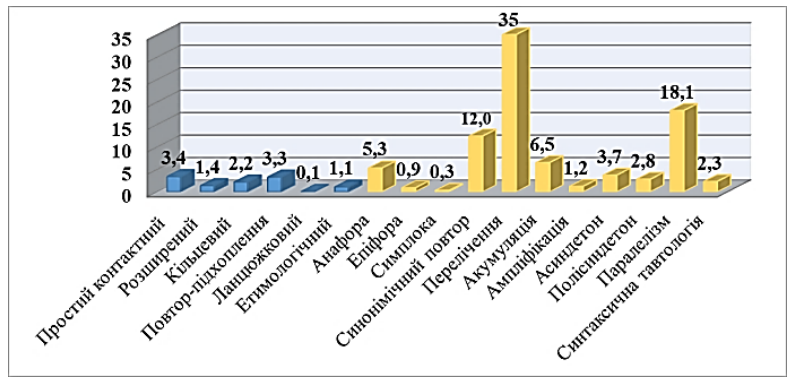

Рис. 1. Відсоткові показники різновидів повтору в романах Шарлотти Бінгхем (загальна кількість одиниць - 4697, 100\%)

${ }^{59}$ Bingham C. Change of Heart. London : Bantam Books, 1994. 469 p.

${ }^{60}$ Скребнев Ю.М. Основы стилистики английского языка. 2-е. изд., испр. М. : Астрель, 2003. 221 с.

${ }^{61}$ Bingham C. Out of the Blue. London : Bantam Books, 2006. 448 p. 


\section{ВИСНОВКИ}

У романах Шарлотти Бінгхем синтактико-стилістична фігура повтору (4697 одиниці; 100\%) є одним із важливих інструментів забезпечення структурно-смислової цілісності тексту, досягнення необхідного стилістичного ефекту і створення певного психологічного настрою читача.

У досліджуваних творах превалює синтаксичний повтор (4164 одиниці; 88,5\%), а лексичний $\epsilon$ менш репрезентативним (533 одиниці; 11,5\%). Синтаксичний повтор (повторення синтаксичної позиції лексичної одиниці/структурно-синтаксичної моделі в умовах достатньої тісноти ряду) насамперед представлено переліченням (35\%), паралелізмом $(18,1 \%)$ і синонімічним повтором (12,5\%). Перелічення $(35 \%)$ у романах авторки використовується задля конкретизації інформації, деталізованого опису предметів і явищ, підкреслення кількості й різноманіття реалій навколишньої дійсності; паралелізм $(18,1 \%)$ надає висловлюванню ритмічного повторення основної ознаки, стану чи властивості, підкреслює смислову рівнозначність усіх частин речення, указує на логічний зв'язок між його частинами та виконує емотивну функцію, а синонімічний повтор (12,5\%) - забезпечує додаткову характеризацію позначуваного.

Лексичний повтор (повторення певного слова/словосполучення в умовах достатньої тісноти ряду) передусім репрезентовано простим контактним $(3,4 \%)$, повтором-підхопленням $(3,3 \%)$ і кільцевим $(2,2 \%)$. Простий контактний повтор $(3,4 \%)$ використовується Шарлоттою Бінгхем для вираження емоційного стану персонажів-мовців або виконує функцію просторово-часової характеризації з указівкою міри чи ступеня. Повтор-підхоплення (3,3\%) відображає розмовне мовлення персонажів або виконує функцію зворотного зв'язку, а кільцевий $(2,2 \%)$ - не лише виділяє важливу в контексті висловлювання інформацію, виконуючи експресивно-стилістичну функцію, а й позначає просторічне мовлення персонажів, реалізуючи стильову.

Перспективи подальшого дослідження вбачаємо у вивченні синтактико-стилістичної фігури повтору в текстах інших англійськомовних авторів у межах жанру роману, а також інших жанрів художньої прози не тільки англійськомовних авторів, а й письменників усього германського ареалу.

\section{АНОТАЦІЯ}

Дослідження присвячено описові синтактико-стилістичної фігури повтору та іiі репрезентації в романах Шарлотти Бінгхем. Визначено, що повтор - це фігура мовлення, яка полягає в повторенні звуків, слів, морфем, синонімів або синтаксичних конструкцій в умовах достатньої тісноти ряду, тобто розташованих достатньо близько один від одного, щоб їх можна було помітити. Розглянуто й типологізовано лексичний i 
синтаксичний повтори, досліджено їх стилістичні функції в романах Шарлотти Бінгхем. Установлено, що в досліджуваних творах переважає синтаксичний повтор, а лексичний $\epsilon$ менш репрезентативним. Розкрито, що 3-поміж різновидів синтаксичного повтору найбільш поширеними $є$ перелічення (35\%), паралелізм $(18,1 \%)$ і синонімічний повтор (12,5\%), а акумуляція (6,5\%), анафора (5,3\%), асиндетон $(3,7 \%)$, полісиндетон $(2,8 \%)$ і синтаксична тавтологія $(2,5 \%)$ розповсюджені менше. Ампліфікація $(1,3 \%)$, симплока $(0,4 \%)$ та епіфора $(0,2 \%) \epsilon$ найменш репрезентативними. З'ясовано, що в романах Шарлотти Бінгхем лексичний повтор репрезентовано передусім такими різновидами, як контактний $(3,4 \%)$, повтор-підхоплення $(3,3 \%)$, кільцевий $(2,2 \%)$. Розширений $(1,4 \%)$ та етимологічний $(1,1 \%)$ повтори в романах авторки наявні в меншій кількості. Випадки вживання Шарлоттою Бінгхем ланцюжкового повтору $(0,1 \%)$ поодинокі.

\section{ЛІТЕРАТУРА}

1. Акимова Г.Н. Новое в синтаксисе современного русского языка. Москва : Высш. шк., 1990. 168 с.

2. Арнольд И.В. Стилистика. Современный английский язык. 13-е изд., испр. и доп. Москва : Флинта : Наука, 2016. 384 с.

3. Ахманова О.С. Словарь лингвистических терминов. Москва : УPCC. 2004. $571 \mathrm{c}$.

4. Бандурко 3.В. Лінгвопрагматичні властивості німецькомовного лірико-поетичного дискурсу «Нової діловитості» : автореф. дис. ... канд. філол. наук : 10.02.04. Херсон : Херсон. держ. ун-т., 2019. 19 с.

5. Бельчиков Ю.А. Нужно воспринимать жизнь во всем ее блеске, красоте и богатстве красок: к 100-летию со дня рождения К.Г. Паустовского. Рус. яз. в шк. 1992. № 2. С. 31-36.

6. Брандес М.П. Стилистика немецкого языка. 2-е изд. Москва : Высшая школа, 1990. 320 с.

7. Власюк Н.И. Синонимический повтор в прагматическом аспекте. Bопросы лингводидактики: сборник научных работ. Гродно : ООО «ЮрСаПринт», 2016. С. 46-48.

8. Волянська Ю.Ю. Типологічні різновиди повтору в сучасній думці. Лінгвістичні студіi. 2010. Вип. 21. С. 188-191.

9. Гальперин И.Р. Очерки по стилистике английского языка. Москва : ЛИБРОКОМ, 2016. 376 с.

10.Гринишин У.М. Синтаксичний повтор як домінанта експресивного маркування постмодерністського тексту. Украӥнознавчі cmydiï. 2013. С. 75-82.

11. Дреева Д.М. Синтаксический параллелизм в немецких свободных ритмах XIX-XX веков (к вопросу об изосинтаксизме верлибра). Вестник Санкт-Петербургского университета. Серия 9 «Филология, востоковедение, журналистика». 2012. Вып. 4. С. 51-59. 
12. Дреева Д.М., Биджелова Б.А. Синтаксический параллелизм в аспекте художественного перевода (на материале стихотворных произведений Ф.Г. Клопштока и И.В. Гете и их переводов на русский и осетинский языки). Современные проблемы науки и образования. 2015. № 2-3. URL: https://www.science-education.ru/ru/article/view?id=23705 (дата звернення: 10.01.2018).

13. Дрыгина Ю.А. Некоторые особенности синтаксического параллелизма в современной английской научной прозе. Eдинство системного и функиионального анализа языковых единии: материалы Междунар. науч. конф. Белгород, 2003. Вып. 7. Ч. 1. С. 149-151.

14.Жук Т.В. Лексичний та синтаксичний повтор в українській народній творчості (на матеріалі українських народних казок) : автореф. дис. ... канд. філол. наук : 10.02.01. Київ : Нац. пед. ун-т ім. М.П. Драгоманова, 2005. 18 с.

15. Кухаренко В.А. Практикум по стилистике английского языка. Москва : Флинта : Наука, 2009. 184 с.

16. Мужеловська Л.В. Повтор як стилістичний засіб творення експресії в поетичному мовленні Олександра Олеся. Педагогічна освіта: теорія і практика. 2012. Вип. 12. С. 224-229.

17. Новрузова Н.С. Синтаксический параллелизм в древнетюркских текстах Вестник московского государственного лингвистического университета. Серия «Гуманитарные науки». 2013. № 23 (683). С. 60-69.

18. Скребнев Ю.М. Основы стилистики английского языка. 2-е. изд., испр. Москва : Астрель, 2003. 221 с.

19. Соколова I.В. Прагматико-комунікативні характеристики категорії повтору в текстах-анонсах : дис. ... канд. філол. наук : 10.02.04. Суми : Сумський держ. ун-т, 2002. 211 с.

20. Сташко Г.І. Роль засобів стилістичного синтаксису в створенні жіночих образів (на матеріалі американських фольклорних пісень). Вісник Житомирського державного університету імені Івана Франка. 2015. № 4 (82). С. 81-86.

21. Стилистика английского языка / А.Н. Мороховский, О.П. Воробьёва, Н.И. Лихошерст, 3.В. Тимошенко. Киев : Вища школа, 1991. $241 \mathrm{c}$.

22. Фінів В.М. Лексичний повтор як когезійно-когерентний засіб у художньому тексті. Прикарпатський вісник НТШ. Слово. 2019. № 3. C. $491-499$.

23. Чабаненко В.А. Стилістика експресивних засобів української мови. Запоріжжя : ЗДУ, 2002. $351 \mathrm{c.}$

24. Чередніченко А.А. Повтори як засіб когезії тексту. Синопсис: текст, контекст, медіа. 2014. № 2. URL: http://nbuv.gov.ua/UJRN/stkm_2014_2_8 (дата звернення: 09.01.2018).

25. Kemertelidze N., Manjavidze T. Stylistic repetition, its peculiarities and types in modern English. European Scientific Journal. Volume 9. Issue 10. 2013. URL: https://www.researchgate.net/publication/309558946_ 
STYLISTIC_REPETITION_ITS_PECULIARITIES_AND_TYPES_IN_M ODERN_ENGLISH (дата звернення: 09.01.2018).

26. Nadiradze I. Lexical repetition as a characteristic feature of the English and Georgian novellas. Scientific enquiry in the contemporary world: theoretical basics and innovative approach : Scientific articles. $7^{\text {th }}$ edition. USA : B\&M Publishing. 2016. P. 101-106.

27. Bingham C. Change of Heart. London : Bantam Books, 1994. 469 p.

28. Bingham C. Distant Music. London : Bantam Books, 2002. 576 p.

29. Bingham C. Grand Affair. London : Bantam Books, 1997. 480 p.

30. Bingham C. In Sunshine or in Shadow. London: Bantam Books, $1991.576 \mathrm{p}$.

31. Bingham C. Magic Hour. London : Bantam Books, 2005. 416 p.

32. Bingham C. Out of the Blue. London : Bantam Books, 2006. 448 p.

33. Bingham C. Stardust. London : Bantam Books, 1993. 576 p.

34. Bingham C. The Daisy Club. London : Bantam Books, 2009. 480 p.

35. Bingham C. The Kissing Garden. London : Bantam Books, 1999. 624 p.

36. Bingham C. The White Marriage. London: Bantam Books, 2007. $480 \mathrm{p}$.

Information about the author: Haidenko Yu. O.,

$\mathrm{PhD}$ in Philology, Associate Professor at the Department of the English Language of Humanities Orientation № 3

National Technical University of Ukraine "Igor Sikorsky Kyiv Polytechnic Institute" 37, Peremohy avenue, Kyiv, 03056, Ukraine 